\title{
DELINEATING SOURCE AREAS TO CAVE DRIPS AND CAVE STREAMS IN AUSTIN, TEXAS, USA
}

\author{
Nico Hauwert \\ City of Austin Watershed Protection Dept., PO Box 1088, Austin, Texas 78767,nico.hauwert@austintexas.gov
}

Brian Cowan

Zara Environmental LLC, 1707 FM1626, Manchaca, Texas 78652, brian@zaraenvironmental.com

\begin{abstract}
Delineating the source area of cave drips and streams (subsurface infiltration catchment area) is important for maintaining high-quality water sources critical for healthy cave ecosystems. In order to focus protection for cave ecosystems, particularly those containing federally listed species, it is necessary to accurately delineate the potential contributing infiltration area with high confidence.
\end{abstract}

Various methods are used in conjunction to delineate subsurface infiltration catchment areas in four Balcones Escarpment sites (Buttercup Creek, Barker Ranch \#1 Cave, McNeil Drive, and Davis Lane). The methods consists of 1) observation and flow measurement of drips, speleothems, pools, and streams under wet and dry conditions to characterize drips as discrete or seepage, 2) cave mapping surveys to determine spatial relations and elevation of drips, speleothems, pools and streams, 3) hydrostratigraphic characterization (dip of beds, faulting, and the rock tendency to perch vadose groundwater downward at a minimum hydraulic gradient), 4) waterquality characterization and comparison with potential sources and 5) dye and chemical tracing. Steps 4 and 5 provide the most direct delineation of source areas based on the detection (or non-detection) of tracers and injection locations. Not all of the methods were applied at all four study sites and some catchment areas are so large that they were not completely delineated without additional investigation.

Mapping the highest elevation of a drip source in a cave limits the surface extent of any infiltration source area. A non-persistent, seepage drip is more likely to originate from soil-moisture drainage close to the cave footprint. Direct tracing of vadose groundwater illuminates the influence played by dip and lower permeable hydrostratigraphic units in perching groundwater and directing vadose flows long distances to drips and cave streams. Injected tracers measured minimum hydraulic gradients of 0.4 to $3 \%$ across lower permeable hydrostratigraphic units and minimum hydraulic gradients of $12 \%$ across higher permeable units. The updip outcrop of the top of a perching lower permeable unit, as well as caves that breach the lower permeable unit, may be used to define the extent of a subsurface catchment area. Through deeper investigation of the caves using various methods together, the mapped subsurface catchment areas are refined to a focused source area. Where insufficient data are available to constrain the boundaries, the subsurface catchment area should always be conservatively overestimated.

\section{Introduction}

Rare cave species in Travis County, Texas, are protected by a federal permit awarded to the City of Austin and Travis County (USFW, 1996). Sixty-two caves were identified that if sufficiently protected could provide suitable habitat for listed endangered karst species and ensure that other rare species of concern would not require federal listing as endangered in the future. Cave species require clean and sufficient water for sustenance, so hydrogeological studies are conducted to identify water catchments that provide direct runoff to the cave entrance (surface catchment area) as well as the overlying area that supports cave drips and cave streams (subsurface catchment area) through subsurface infiltration. Since the delineation of surface catchments is considerable more direct and is described elsewhere (Hauwert, 2009), this paper pertains only to delineation of subsurface catchment areas, except where surface catchments contribute to areas of subsurface infiltration that supply the studied drips.

Basic methodology for delineating source areas are described by Quinlan et al (1995) and Goldscheider and Drew (2007). For delineating subsurface catchment areas for cave drips and cave streams of the Edwards Aquifer, it is important to have an understanding of 
recharge and storage through the soils and epikarst. In the 1980s, studies were conducted that examined recharge within the Barton Springs Segment, how groundwater moves through the aquifer. Using a water budget approach based on stream gauging and rainfall measurements. Assuming that all recharge in Barton Creek channel of the recharge zone discharges from Barton Springs, it was calculated that $85 \%$ of rainfall was lost to evapotransporation, $5 \%$ of rainfall recharged within the major creek channels, and only $0.89 \%$ of rainfall infiltrated the ground and recharged the aquifer within the intervening areas between the major creek channels (Woodruff, 1984). However, the 1980s water balance was invalidated in 1996, when direct groundwater tracing and water level mapping revealed that the entire portion of Barton Creek where flow loss was measured and attributed to recharge is not actually within the groundwater basin contributing to Barton Springs (Hauwert, 2004; Hauwert, 2009). That error alone comprised $28 \%$ of total recharge to Barton Springs in the water budget, and explains why the Edwards Aquifer was erroneously attributed a recharge value similar to those measured over the Eagle Ford Shale (Hauwert, 2009). Hydrogeologic studies commonly fail when based on an incomplete understanding of groundwater source areas, as well as often erroneous assumptions are that only major creeks supply significant recharge, that upland soils do not allow infiltration into the underlying bedrock, that groundwater flow is slow, and that groundwater transport generally has high dispersion and attenuation (Hauwert, 2009; Hauwert, 2012a).

Karst aquifers typically show recharge values of 20 to $60 \%$ of rainfall because of naturally efficient recharge structures (Hauwert, 2009). Initial site-specific measurements from Central Texas used climate towers in Uvalde County discovered that of measured rainfall, $65 \%$ was lost to evapotranspiration, $5 \%$ to runoff, and $30 \%$ to recharge (Dugas et al, 1998). Climate towers combined with flumes provided a more direct measurement of recharge since they quantify roughly $70 \%$ of the rainfall budget as opposed to roughly 5 to $15 \%$ of the rainfall budget measured through streamflow loss. A 1.4-year site-scaled water balance within the Barton Springs Segment used an eddy covariance tower, rain gauges, and flumes to measure rainfall components as $68 \%$ evapotranspiration, $3 \%$ runoff that entered the drain of an internal drainage basin, and the remaining
$29 \%$ recharged the aquifer from upland slopes. Using gauging station data distinguished by traced groundwater divides, about $63 \%$ of rainfall was estimated to be lost as evapotranspiration, $22 \%$ recharged over the Edwards Aquifer recharge zone, and $15 \%$ discharged into major creeks and ran off downstream of the recharge zone (Hauwert, 2013).

The general influences of geology on cave development and vadose flow are described by White (1988); Palmer (2007), and Goldscheider and Drew (2007). The degree to which stratigraphy influences groundwater flow varies with permeability contrast and aquiclude thickness, as well as the degree of faulting (Goldscheider, 2005). Veni (1992) summarized the effects of geology on cave development described by White (1988) and Ford and Williams (1989) including: vertical cave shafts generally develop above the water table and are associated with beds of lower permeability or lower solubility; horizontal cave passages develop in high permeability beds; caves typically become impassible at common lower permeable/lower solubility horizons or due to sediment fill; and springs discharge near horizons of permeability contrast and their discharge is proportional to the size of its catchment area. Rose (1972), Maclay and Small (1986), and Small et al. (1996) described the general characteristics of the hydrostratigraphic members of the Edwards Aquifer (Table 1). Hauwert (2009) described in greater detail how the hydrostratigraphic properties of the Edwards Aquifer influence cave development and groundwater flow within the Barton Springs Segment of the Edwards Aquifer.

Geologic structure strongly influences vadose flow in karst areas. In unconfined areas of karst aquifers, vadose flows tend to flow in a downdip direction where stratigraphic dip is present (Palmer, 1977; Ginsberg and Palmer, 2002; Veni, 1992). Downdropped faults often create a hydraulic gradient within the unconfined portion of Edwards Aquifer that simulates the effects of stratigraphic dip, even where local dip is absent (Hauwert, 2009). Rock-strata within the Edwards Aquifer may also dip nearly parallel to scissor fault directions within ramp structures (Collins, 1995).

\section{Methodology}

The subsurface catchment area for a cave drip or cave stream can be constrained within a defined area simply by mapping the surface extent of any connected 
Table 1. Hydrostratigraphic units of the study areas. Modified from Small et al. (1996) and Hauwert (2009). While the Basal Nodular Member appears equivalent to the Comanche Peak and Walnut Formations of North Austin, it has not been formally correlated.

\begin{tabular}{|c|c|c|c|c|c|c|}
\hline $\begin{array}{l}\text { Hydrogeologic } \\
\text { subdivision }\end{array}$ & Group & Formation & Member & $\begin{array}{l}\text { Full Thickness } \\
\qquad(\mathrm{m})\end{array}$ & Lithology & General Hydrogeologic Properties \\
\hline & & Del Rio & & $15-18$ & Clay & Low permeability clay \\
\hline \multirow{7}{*}{ 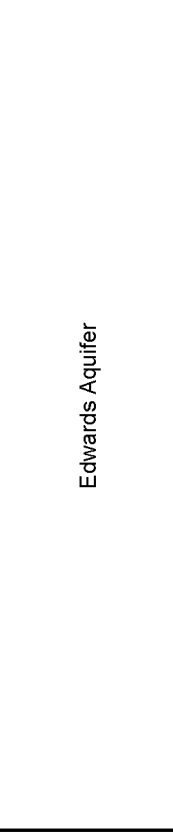 } & Washita & Georgetown & & $12-18$ & $\begin{array}{c}\text { Nodular fossilferous } \\
\text { limestone }\end{array}$ & $\begin{array}{l}\text { Low permeability overall with local vertical fissure } \\
\text { development }\end{array}$ \\
\hline & \multirow{6}{*}{ Edwards } & Person & $\begin{array}{l}\text { Leached and } \\
\text { Collapsed } \\
\text { undivided }\end{array}$ & $0-21$ & $\begin{array}{l}\text { Wackestone and } \\
\text { grainstone with } \\
\text { mudstone matrix }\end{array}$ & $\begin{array}{l}\text { High permeability with extensive horizontal and } \\
\text { vertical cave deveopment }\end{array}$ \\
\hline & & & $\begin{array}{l}\text { Regional } \\
\text { Dense }\end{array}$ & $4.5-10$ & $\begin{array}{l}\text { Well-sorted fissile } \\
\text { mudstone }\end{array}$ & $\begin{array}{l}\text { Local aquitard frequently breached with vertical } \\
\text { fissures and shafts. }\end{array}$ \\
\hline & & \multirow{4}{*}{ Kainer } & Grainstone & $14-18$ & $\begin{array}{c}\text { Massive, resistant, } \\
\text { miliolid/ chondrodont } \\
\text { grainstone }\end{array}$ & $\begin{array}{c}\text { Highly variable moderate to high permeability. Tight } \\
\text { corkscrew cave passages and enlarged bedding } \\
\text { plane rooms. Commonly serves as competent roof } \\
\text { over Kirschberg Mbr }\end{array}$ \\
\hline & & & Kirschberg & $12-23$ & $\begin{array}{l}\text { Crystalline limestone } \\
\text { and pulverulite }\end{array}$ & $\begin{array}{c}\text { High permeability with extensive cave development } \\
\text { associated with pulverulitic beds. Extensive } \\
\text { dissolution and breakdown. }\end{array}$ \\
\hline & & & Dolomitic & $9-43$ & $\begin{array}{l}\text { Highly bedded with } \\
\text { sandy or dolomitic } \\
\text { matrix }\end{array}$ & $\begin{array}{l}\text { Moderate fissure-dominated permeability with } \\
\text { significant cave development }\end{array}$ \\
\hline & & & $\begin{array}{c}\text { Basal } \\
\text { Nodular }^{\star}\end{array}$ & $16-32$ & $\begin{array}{c}\begin{array}{c}\text { Fossilferous, nodular } \\
\text { limestone }\end{array} \\
\end{array}$ & $\begin{array}{l}\text { Low permeability breached by vertical pits and } \\
\text { fissures. Produces many minor springs. }\end{array}$ \\
\hline $\begin{array}{l}\text { Upper Trinity } \\
\text { Aquifer }\end{array}$ & Trinity & $\begin{array}{l}\text { Upper Glen } \\
\text { Rose }\end{array}$ & & $100-150$ & $\begin{array}{l}\text { Alternating massive } \\
\text { limestone, dolomite } \\
\text { and marl layers }\end{array}$ & $\begin{array}{l}\text { Overall low permeability with conduit network } \\
\text { supporting abundant springs/wells. Hydraulic } \\
\text { connection with Edwards Aquifer and cave } \\
\text { development documented in some areas. }\end{array}$ \\
\hline
\end{tabular}

land surface elevation than the cave. This approach is appealing because it requires very little data from the cave other than the total cave depth and surface topography, and includes the entire actual source area to cave drips with high confidence. However, subsurface catchment areas defined based solely on the cave depth projected topographically on the surface typically extend for long distances from the cave, greatly overestimating the actual subsurface catchment area. The purpose of deeper hydrogeological study of the cave is to allow the investigator to limit the size of the defined subsurface catchment area, but include all of the source area for subsurface infiltration to the cave with high confidence. The methods utilized in studies to map subsurface catchment areas involve a combination of cave surveys, geological framework mapping, water-quality sampling, and introduced tracers. Note that in each of the study areas, emphasis is placed on some of the methods that were most useful for the specific location.

\section{Cave Surveys}

The depth and lateral extent of the cave constrains the subsurface catchment area. The lateral extent of the cave beneath the ground is known as the cave footprint. Without the completion of additional study beyond mapping the cave, the lowest elevation of the cave can be used to eliminate areas of lower elevation as being outside the subsurface catchment area.

The cave is mapped from an entrance survey point using station-to-station measurement of distance, azimuth, and inclination as described by Dasher (1994), Jeannin et al (2007), and Ochel and Shade (2013). Distance is measured using a nylon tape or Bosch laser survey. Azimuth is measured using either a Brunton and/or Suunto tandem compass. Magnetic declination was set on the compasses and verified by recording test azimuths to surface objects over $30 \mathrm{~m}$ away and locating the start and finish with a Trimble XT. Inclination was measured 
with a Tandem inclinometer and Brunton compass inclinometer. Where possible, forward and back shots were taken between each station and any discrepancies were resolved through repeat measurement.

Existing cave maps provide valuable information but generally do not provide sufficient information alone. Drips in the caves were rarely mapped on existing cave maps for the study area. Most caves referenced in this report were resurveyed even though existing maps were available. The difference between two cave surveys was used as a fair indication of where the cave footprint lies. Cave radio location was used on longer caves to locate the surface position and depth of several stations within the cave. The elevation of the cave drip is derived from the cave survey and/or cave radio location. As general criteria, the subsurface catchment area should extend at least $100 \mathrm{~m}$ beyond the cave footprint.

\section{Characterization of drips and cave streams}

If the highest point of origin of a cave drip or cave stream can be established, then that drip horizon, rather than the bottom of the cave, can be used to delineate a source area. Note that drips within the cave may originate from different sources unless associated by physically following the flow from one point to another, analyzing water-quality similarity, or tracing the flows. A general summary of cave drip characterization is provided by Jeannin et al (2007).

Cave drips are characterized as discrete or seepage. A discrete drip or cave stream may flow from an open aperture/conduit/cave. Its discharge is focused in one or a few locations. A seepage drip has discharge distributed from many formations across a ceiling. The persistence of a drip or cave stream is characterized at various times under wet and dry conditions, particularly during or shortly after an intense storm where the soils are saturated. Methods used to quantify cave drip rates include using a graduated plastic cylinder to measure the drip volume over a measured time interval. Plastic Rainwise tipping buckets with Onset Microstation data loggers are used on some drips to measure drip rates continuously, allowing changes in drip rate to be correlated with rain event cycles or anthropogenic sources such as swimming pool draining or utility line leak. In a cave room with widely dispersed cave drips, one cave drip rate volume is measured to estimate drip volume per drip, and other drips in the room are quantified by quietly counting drips over a two-minute interval, and later quantifying the drip rate of the entire room. Cave streams are typically measured by filling a waterproof cave pack of measured volume by capturing the entire flow at a pour-off point.

Speleothem types may be used to characterize sources. Stalactite, stalagmite, column, flowstone travertines, and bacon rinds may be associated with discrete drips. Soda straws are typically associated with seepage drips. Popcorn is typically associated with seepage flow through pores, although it is possible that a discrete source is transmitted through a porous media, such as a pulverulite.

When accessing caves for studies it is recommended and possibly required by local permitting to have trained cave specialists and cave biologists. A cave specialist can ensure the cave is entered safely and determine where specialized techniques such as negotiating vertical techniques or tight crawls are required. Cave biologists frequently accompanied trips into caves during this study to minimize impacts to the cave ecosystem.

\section{Hydrostratigraphic Mapping and Characterization}

The general properties of the rocks and the geological framework, such as rock dip and fracturing of the rocks, can be used to understand the basis for groundwater flow horizontally and vertically. Detailed mapping of the surface and subsurface geology is an important step for delineating subsurface catchments.

\section{Hydraulic gradient}

One criterion for delineating subsurface catchment areas is based on the properties of the rocks between the surface and cave drip. Using tracing and direct observation of cave passages through various hydrostratigraphic units, the vertical movement of water can be quantified in terms of a minimum vertical hydraulic gradient. This criterion can be applied only to sites where the hydrostratigraphic units are accurately mapped on the surface and subsurface.

In highly permeable and soluble rocks, water will tend to descend relatively steeply even where fractures, faults and fissures are not present. In low permeable rocks, groundwater flow is more likely to "stair step" downward, flowing horizontally along stratigraphic dip and periodically descending vertically along fissures 
and shafts. In low-permeable limestones and dolomites dissolution is strongly enhanced along fractures, perching above less-permeable beds and descending down fissures and shafts.

Within the highest permeability hydrostratigraphic units, such as the Leached and Collapsed Members, Kirschberg, and Grainstone Members, while cave passages may extend horizontally through these units, the passages were formed in the phreatic zone, and under unsaturated zone conditions small flows have not been observed to extend far horizontally before descending (Hauwert, 2009). Note that where cave passages in overlying permeable units overlie relatively lower permeability beds, such as cave passages within the Leached and Collapsed Member over the Regional Dense Member, it is the underlying low-permeability bed that controls the hydraulic gradient. Lower permeability units within the Basal Nodular Member/Walnut Formation, Regional Dense Member, and the Dolomitic Member tend to perch groundwater for some distance until breached by shaft. So the lower permeability units have both very low and very high vertical gradients of vadose groundwater flow.

The property of hydrostratigraphic units to perch groundwater can be quantified as minimum hydraulic gradient that is the distance that a tracer travels divided by vertical depth above or through that unit. Based on the mapped hydrostratigraphic units between the surface and cave discharge, the mapped subsurface catchment area should extend at least beyond the minimum hydraulic gradient measured for those rock units unless other criteria exist, such as direct tracing used to indicate a higher hydraulic gradient and smaller source area. All units potentially have a high hydraulic gradient (vertical), such as where shafts or fissures are present. Definition of the minimum hydraulic gradient from a drip to the surface provides a criterion to limit the lateral extent of potential source area.

The minimum hydraulic gradient is tested on a siteby-site basis through the various hydrostratigraphic members through which the groundwater travels. For the sites traced, the hydrostratigraphic units are mapped across the surface, in caves, in logged wells, and from cores to define the subsurface extent between the surface and entire cave depth. It is possible that a lower gradient exists across a hydrostratigraphic unit than we tested, so this criteria should be used with caution to limit the size of the subsurface catchment area, particularly in the updip direction of a cave drip, where a persistent discrete drip suggests a larger source area, and obviously where a traced flow path indicates a lower hydraulic gradient.

\section{Geologic Framework: Stratigraphic Dip and Faulting}

In order to examine geological controls of vadose groundwater flow, the geological framework is mapped, including stratigraphic dip and faults. In areas between mapped faults, the location and elevation of distinctive marker beds are located using global positioning systems within $1 \mathrm{~m}(3 \mathrm{ft})$ horizontal and vertical accuracy. Using a three-point problem solution, the maximum dip direction and maximum dip magnitude are calculated (Compton, 1962). The stratigraphic dip directly measured at the site scale, and the measured local dips rarely coincided with regional dip reported in the literature. Single outcrop and cave measurement of small-scale dip seemed to vary more with local collapse and generally were not representative of overall dip within fault blocks.

The subsurface catchment area typically extends in the stratigraphic updip direction from the cave discharge. Despite the general rule of downdip vadose flow, exceptions have been observed where vadose flow essentially ignores stratigraphic dip and follows faulted preferential flow routes directly to a local spring site, sometimes perpendicular to down dip and down faulting direction (Hauwert, 2009). Faults are generally poorly exposed in the Austin area and are most commonly mapped using abrupt change in surface hydrostratigraphic units. Detailed site geology mapping is generally necessary to distinguish elevation declines in marker beds due to faulting, stratigraphic dips or other geologic structures.

If a lower permeable hydrostratigraphic unit is discovered to have a defining influence on perching groundwater flow, then the extent of updip outcrop of the top of the low-permeable unit was generally used for defining the extent of subsurface source area, even where minimum hydraulic gradient values define smaller subsurface catchment areas.

Other structures that may limit the extent of the subsurface catchment area are caves that breach lower permeable perching units or descend below the drip horizon in the studied cave. These are known as breach structures in 
this study. In cases where narrow topographic saddles were connected by continuous higher elevation to the cave drip, it was deemed unlikely that a vadose flow path would follow a ridge or perhaps take erratic turns rather than discharge into an adjacent tributary.

\section{Water-Quality Characterization}

Water quality similarities help associate drips within the same cave or characterize sources to those cave discharges. Water-quality association is not as direct as tracing, therefore involving more interpretation. Waterquality characterization is necessary where tracing cannot be conducted to associate drips with a source area or where tracer was not recovered at specific discharges. The source water sampling parameters included alkalinity, calcium, carbon, chloride, fluoride, magnesium, potassium, sodium, sulfate, bromide; trace metals: aluminum, arsenic, boron, cadmium, chromium, copper, iron, lead, nickel, strontium, zinc; nutients: nitrate + nitrite, ammonia, phosphorus; and total suspended solids. The samples were filtered and preserved for most parameters. Bacteria samples are collected using both grab and autosamplers. When collected using autosamplers, blank bottles are tested for total coliform and E. coli to test for bottle contamination.

\section{Dye and Chemical Tracing}

Dye traces successfully traced groundwater flow paths over $32 \mathrm{~km}$ (20 mi) in the Barton Springs Segment (Hauwert, 2009). Because aquifer-wide tracing utilizing sodium fluorescein/uranine, eosine, rhodamine wt, and sulforhodamine $b$, and phloxine $b$ is nearly continuously being conducted within the Barton Springs Segment, those tracers could not be used in our short vadose tracing. Organic tracers are also notoriously sorbed by organic debris and sediment and are most effective when injected in open apertures. The advantage of organic tracers is that they can be monitored continuously using charcoal receptors for dyes and cotton receptors for optical brightners. For soil tracing we frequently use the optical brightners tinopal and direct yellow 96, as well as the dye pyranine, even though they are not ideally suited for soil tracing, and frequently not recovered alongside simultaneously injected chemical tracers. All analysis for dyes and optical brighteners was conducted by Ozark Underground Laboratory in Protem, Missouri.

Chemical tracers commonly used include potassium bromide $(\mathrm{KBr})$, ammonium carbonate $\left((\mathrm{NH} 4)_{2} \mathrm{CO}_{3}\right)$, and $10,000 \mathrm{mg} / \mathrm{l}$ iron standard solution (Fe). The disadvantage of chemical tracing is that if the sampling intervals selected are too wide, a short breakthrough pulse might be missed and a composite sample may dilute the pulse to the extent that it is undistinguishable. A frequent sampling cycle can also be expensive and labor intensive. Analysis for $\mathrm{K}, \mathrm{Br}, \mathrm{NH}_{3}$, alkalinity, and iron are conducted by the Lower Colorado River Authority lab in Austin, Texas. All tracers in this study were flushed using natural rain events except for the Buttercup Creek site, where organic tracers were injected into cave streams.

Where tracers targeted cave species preserves, biological surveys of the caves were conducted by permitted cave biologists to verify that the amount and type of tracer were not visibly affecting the cave ecosystem. The type of tracers and injection amount were similarly considered so as not to create a nuisance or health hazard. At the concentration of tracers in the phreatic zone, the tracers were relatively benign, especially compared to actual contamination sources that have affected or could potentially affect these water supplies. The risk of potential impacts to the species or water supply users can be considered in light of potential impact sources that may be much worse than the tracers used. The information gleaned by direct tracing can help focus long-term protection efforts as opposed to less effective disperse and resource intensive efforts over a large area that may offer limited protection.

\section{Study Sites}

Four study sites include Buttercup Creek, Barker Ranch, McNeil, and Goat/Blowing Sink karst preserves (Figure 1.)

Buttercup Creek Study, Northern Segment

In 1997, two organic dyes were injected into cave streams of Marigold Cave and Whitewater Cave by Mike Warton \& Associates of Cedar Park, Texas. This study was funded by Lumbermans Investment Corporation and the report submitted to US Fish and Wildlife Service (Hauwert and Warton, 1997). Monitoring was conducted by Nico Hauwert and Mike Warton \& Associates using charcoal receptors and grab samples. The caves included horizontal passages and shafts through the Comanche Peak Formation and Walnut Formations that underlie the Edwards Formation in the Northern Segment of the Edwards Aquifer. This study differs from the other three study site examples in that flow from cave streams to 


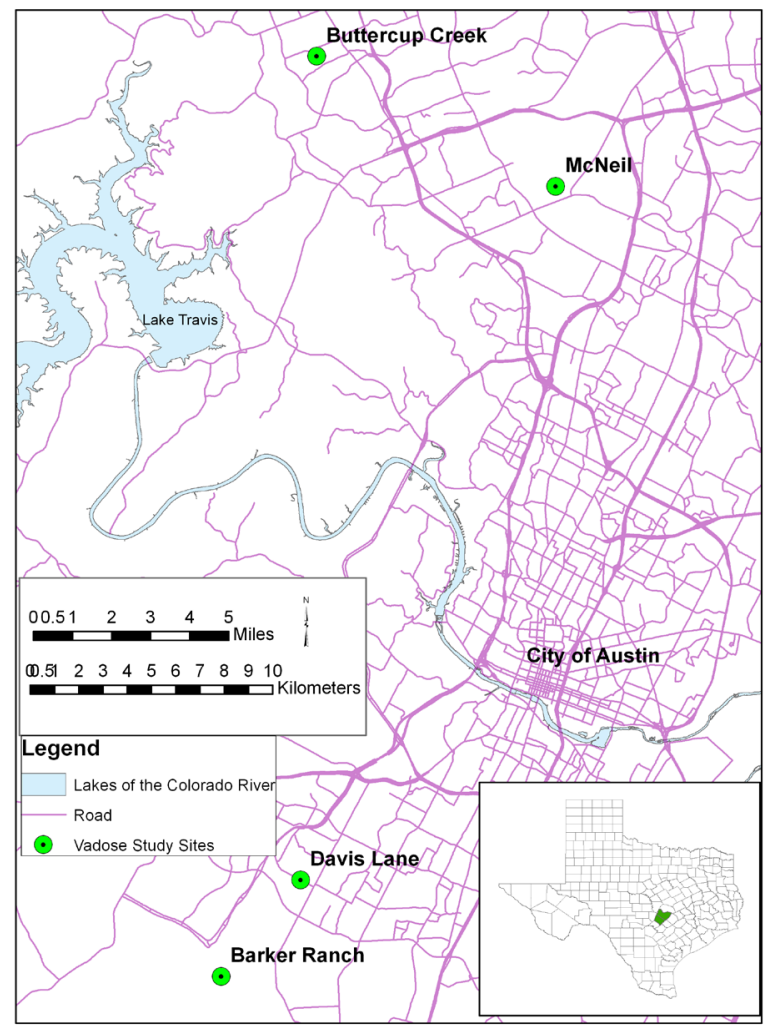

Figure 1. Location of four study sites, Austin, Texas, USA.

surface discharge spring were traced, rather than surfaceto-cave drip or cave stream.

\section{Barker Ranch \# 1 Cave}

Barker Ranch \#1 Cave is a relatively shallow upland cave of relatively high topography. One large room adjacent to the entrance has multiple drips that are persistent (Figure 1).

The cave is developed within the Grainstone and Kirschberg Members of the Edwards Group. A soil tracing study funded by the City of Austin Watershed Protection Department in 2007 involved pouring tracers at six surface locations across the site and monitoring Barker Ranch \#1 Cave drips for any breakthrough. Natural rain events were used to flush the tracers along with 15 liters of water solvent for powder tracers (Cowan et al., 2007). The chemical tracers used were potassium bromide $(\mathrm{KBr})$, ammonium carbonate $\left((\mathrm{NH} 4)_{2} \mathrm{CO}_{3}\right)$, iron standard $(\mathrm{Fe})$, sodium chloride $(\mathrm{NaCl})$, and potassium iodide (KI). Three traces were repeated to verify results or replace a failed trace. Supplemental organic tracers were used alongside chemical tracers, including dyes sulforhodamine b (SRB) and pyranine, as well as optical brightener direct yellow 96 (DY96). Even though the drips in Barker Ranch \#1 are relatively persistent for months after rain, the onset of drought following the third round of simultaneous tracing eventually led to the drips in Barker Ranch \#1 drying for several years, resulting in the end of injections to Barker Ranch \#1 Cave.

\section{Study along McNeil Drive}

Several caves near McNeil Drive contain listed endangered species, including McNeil Bat Cave, Weldon Cave, No Rent Cave, and Fossil Garden Cave. The study involved surface mapping of the area, examining local quarries and drilling bores and geotechnical borings to gain subsurface geology data and measure local dip (Hauwert, 2010). Three of the four caves were remapped relative to professionally surveyed surface monuments at the cave entrance. The drips were observed under varying climatic conditions. No tracers were injected for this study.

\section{Study along Davis Lane}

A study of Goat Cave, Maple Run Cave, and Blowing Sink Cave was conducted by Nico Hauwert of City of Austin and Brian Cowan and support staff from Zara Environmental in 2012, funded in part by City of Austin Public Works Department and by a spill simulation Capital Improvement Project by the Watershed Protection Department. The study involved surface and subsurface geological mapping, cave and drip mapping, water-quality sampling of surface drips and runoff, and tracer injections at various surface locations. Chemical tracers (potassium bromide, ammonium carbonate, and iron) were used, along with optical brightners tinopal, direct yellow 96, and pyranine. A cave radio survey of Maple Run Cave was conducted.

\section{Results}

In the three cave drip studies, the cave drips were found to be localized in specific areas and not distributed throughout the cave. Both seepage and discrete drips were encountered. The localization of drips within the caves suggests that epikarst and vadose flows converge along common flowpaths rather than diffusely flowing through small pores within the entire rock column.

\section{Butfercup Creek}

The two tracers injected, fluorescein and RWT, moved $5 \mathrm{~km}$ (3 mi) southwest, apparently along a mapped fault and discharged from Blizzard Springs, which discharged on the west (opposite) side of Cypress Creek. Blizzard 
Springs discharges from the base of a bluff, about $5 \mathrm{~m}$ $(15 \mathrm{ft})$ below the contact of the Walnut Formation in the upper Glen Rose Formation. The Walnut Formation is generally less soluble than the overlying Edwards Formation, but hosts extensive cave development along fissures. Although local mapping of stratigraphic dip was not included in this study, mapping elevation changes several kilometers south have shown a relatively consistent eastward decline in the contact of the Edwards and Walnut formations. Since the tracers were injected within cave streams that likely have large contributing source areas, only a portion of the subsurface catchment area was defined.

\section{Barker Ranch \# 1 Cave}

Four of the six injection sites were successfully traced to drips in Barker Ranch \#1 Cave (Figure 2). The initial injection of $\mathrm{KBr}$ in site 1 resulted in a clear breakthrough of bromide, first arriving within three to seven hours, and a later breakthrough of potassium following a second rain event (Figure 3). A number of nearby caves descend below the elevation of drips within Barker Ranch \#1 Cave, and are expected to serve as breach structures to funnel vadose flow below the studied drips. Most injection sites were small soil-filled depressions and open solution cavities where runoff naturally localizes and infiltrates. However, site 5 was intentionally selected as a soil site devoid of obvious macropores or depressions. The drip horizon outcrops within $120 \mathrm{~m}$ (400 ft) to the east, north, and south of Barker Ranch \#1 Cave.

Two chemical tracers tested on Barker Ranch \#1, potassium iodide and sodium chloride, were found unsuitable for tracing here and were not reapplied. Background concentrations of chloride in the drips were too high to be able to distinguish breakthrough concentrations on the order of $0.1 \mathrm{mg} / \mathrm{l}$. We were unable to locate a local laboratory to analyze for iodide.

The organic tracers were not detected in Barker Ranch \#1 after four injections. In two cases (sites 4 and 6) associated chemical tracers were not detected above background concentrations, indicating that those injection sites are not within the subsurface catchment area to Barker Ranch \#1. In the remaining two cases from sites 2 and 3 that were traced to Barker Ranch \#1 chemically, it is possible an insufficient mass of organic tracer was injected and the tracers were sorbed by soils and organic-rich materials. Sometime less than a month after pyranine was injected at site 4 on May 27, 2007, pyranine was measured in a charcoal receptor in well 58-50-511, which is $5.3 \mathrm{~km}$ northeast. This is a reasonable hit since that well has had periodic tracer hits from upgradient traces. The well is mapped to be downgradient along groundwater flow paths near Barker Ranch \#1, and three-week interval background receptors placed in the well since March 12, 2007, did not detect the tracer.

Based on the tracing results, local breach structures, drip characterization, and drip elevation, an area encompassing the subsurface catchment area was mapped (Figure 2). This area could potentially be further constrained by additional traces.

\section{McNeil Drive Study}

Surface geology mapping, subsurface mapping in caves, two borings, and one core allowed subsurface mapping of geological framework expected to influence groundwater flow. All of the caves studied were developed within the Grainstone and underlying Kirschberg Members of the Edwards Group. Maximum stratigraphic dip was measured to be northwest and no faults were mapped between the caves (Figure 4). The subsurface catchment area was mapped based on the cave footprint, a minimum hydraulic gradient of $10 \%$ from the mapped cave drips. The presence of one persistent and relatively deep discrete drip in the Rhadine Room of McNeil Bat Cave necessitated including a possible subsurface catchment area to the outcrop of overlying rock in the updip area as far as $600 \mathrm{~m}$ $(2,000 \mathrm{ft})$ to the southeast. In this case, the application of tracers might help further refine the subsurface catchment area to a smaller area. The subsurface catchment areas for Fossil Garden, No Rent, and Weldon caves could be adequately delineated to a reasonable area based on outcrop of overlying rock in the updip area and hydraulic gradient from the mapped cave drips.

Three borings encountered groundwater within both the Dolomitic Member and Walnut Formation, beneath the elevation of the studied caves. Although the study of groundwater flow beneath the preserve caves was beyond the scope of the study, the elevation of groundwater within the Dolomitic Member and presence of spring-fed Walnut Creek to the south and southwest of the study site suggest that the perched groundwater is flowing south or southwest, which is surprisingly in the measured updip direction (Figure 4). This evaluation 


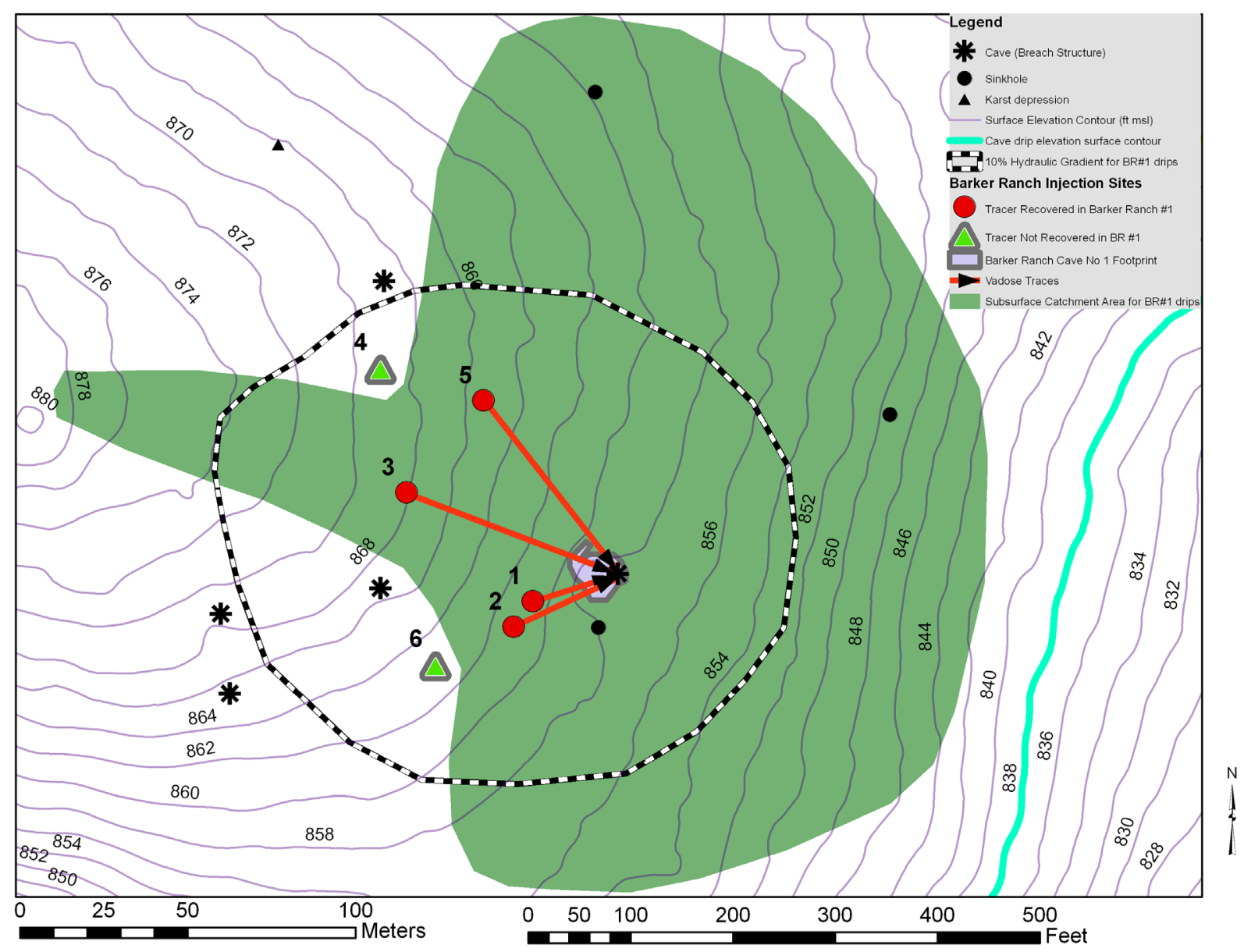

Figure 2. Tracer injection sites associated with Barker Ranch \# 1 Cave drip study. Note the subsurface catchment area interpretation is constrained by the surface elevation corresponding to the cave drips, by 6 vadose trace sites, nearby caves that serve as breach structures, and 10\% minimum hydraulic gradient for the Grainstone and Kirschberg Members overlying the drips.

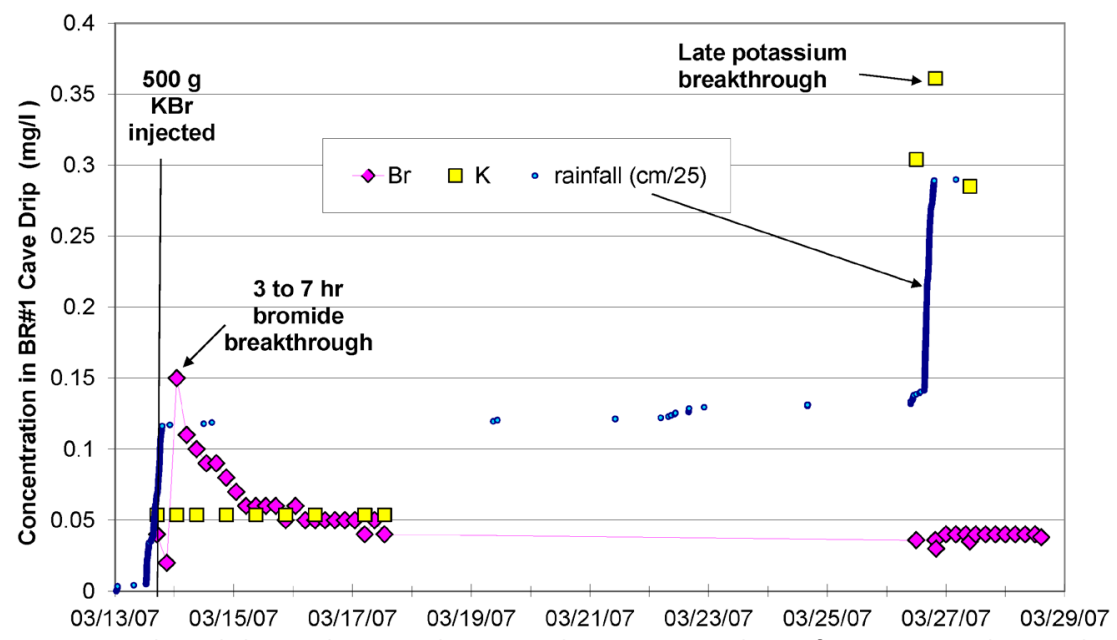

Figure 3. Concentration breakthrough in Barker Ranch \# 1 Cave drip of potassium bromide $(\mathrm{KBr})$ tracer injected in a small soil-filled depression (site 1, Figure 3) about $30 \mathrm{~m}$ from the entrance. The injection was flushed by a natural rain event. Bromide peaked three to seven hours after injection. Sampling resumed for a second event after a nine-day pause and sampling detected a late potassium pulse breakthrough. 


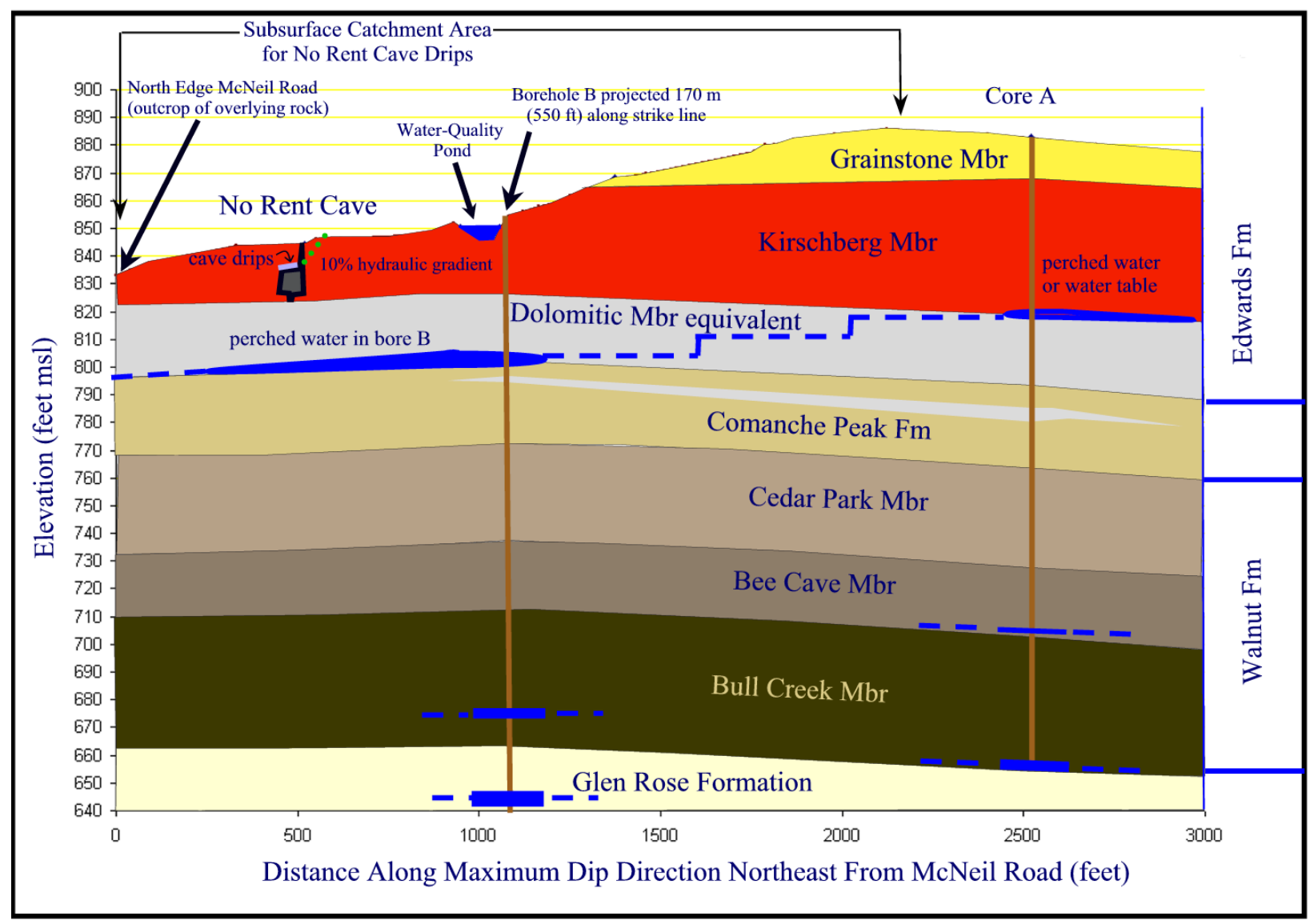

Figure 4. Geologic cross section of McNeil Drive Site, through No Rent Cave. Since the persistent drips could potentially be supplied in part by a water-quality pond that captures storm-water runoff, the subsurface catchment area was extended to include the entire contributing surface catchment area for the pond.

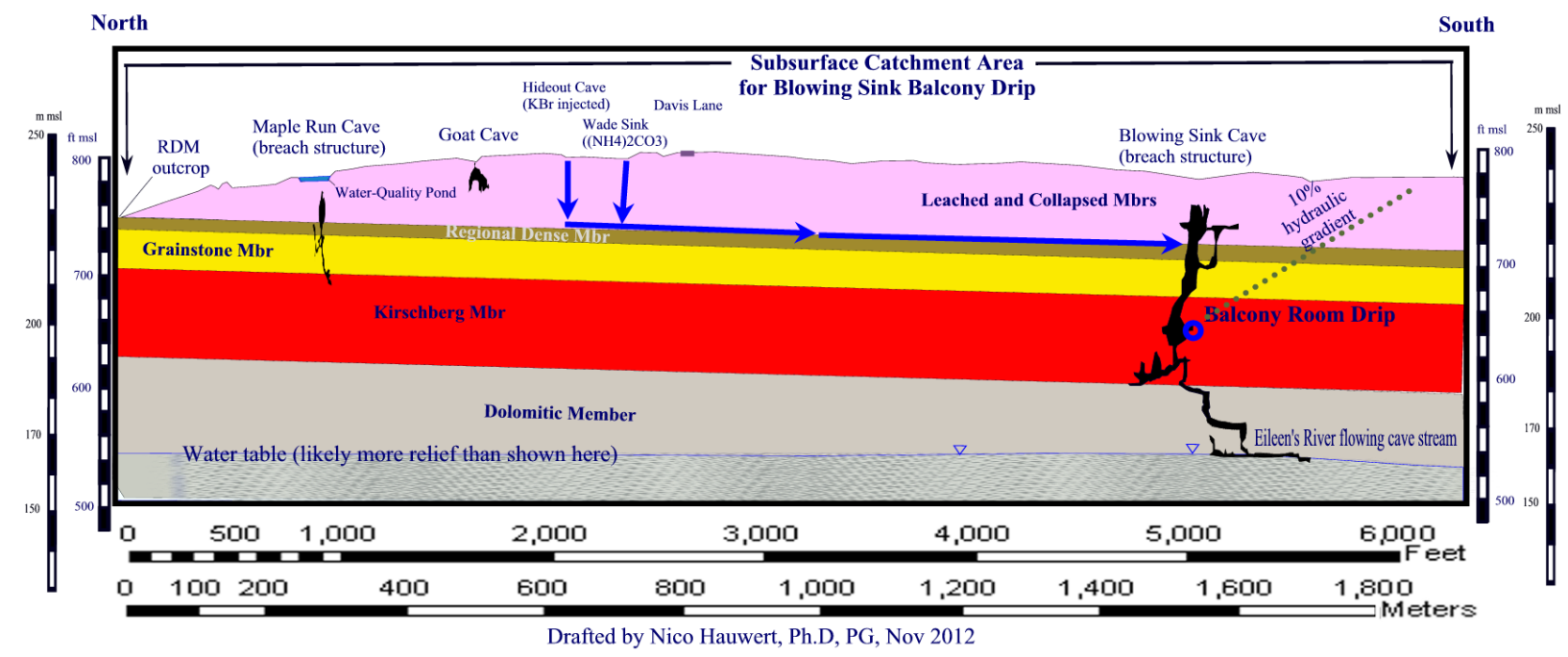

Figure 5. Geologic cross section of Davis Lane and Subsurface Catchment Area to Balcony Room Drip of Blowing Sink Cave. 
of groundwater flow within the Dolomitic Member below the studied drips is not definitive without further study. It is possible the groundwater encountered in the borings is not hydraulically connected, but may suggest exceptions to the general rule of downdip perched groundwater flow.

\section{Davis Lane Study}

The location and characterization of cave drips in Goat, Maple Run, and Blowing Sink caves was initially accomplished by observing the inside of the caves after an intense hurricane-related storm in 2010.

Geological mapping indicated that much of the surface in the study area near Davis Lane was underlain by the permeable Leached and Collapsed Members. A shallow depth below the surface, the Regional Dense Member (RDM) was present (Figure 5). The RDM was observed in Maple Run Cave and at a lower elevation in Blowing Sink Cave. While the clay-rich RDM tends to locally perch groundwater, a number of local caves were mapped to descend through and below the RDM, effectively acting as drains to allow the perched groundwater to descend toward the phreatic zone.

Seven surface locations were selected for tracing. Tracers injected into Winterwoods and Sunspot caves were both detected in the phreatic cave stream for Blowing Sink Cave. Tracers injected in Wade Sink and Hideout Sink were both detected in the vadose Balcony Drip of Blowing Sink Cave three days after injection. This drip is approximately 900 $\mathrm{m}(3,000 \mathrm{ft})$ south of the injection sinks. It appears that groundwater perched over the RDM, descending through a breach in the RDM at Blowing Sink Cave.

\section{Hydraulic Gradient}

Based on the vadose traces included in this study, minimum hydraulic gradients for various hydrostratigraphic units of the Edwards Aquifer can be characterized. Table 2 below shows the measured results through the tested units.

Based on the testing thus far, minimum hydraulic gradients in the Leached/Collapsed and Regional Dense Members are 3\%. Higher minimum hydraulic gradients of $12 \%$ were measured in the Grainstone and Kirschberg Members, and lower minimum hydraulic gradients of $0.4 \%$ were measured across the Walnut Formation. We use $10 \%$ in place of $12 \%$ for high permeable units both for ease of calculation and because it is more conservative. Although the Dolomitic Member has not been tested yet, observations of water perching laterally over $90 \mathrm{~m}$ (300 ft) in Flint Ridge Cave over the rhythmic beds of the Dolomitic Member, and overall perching of groundwater observed in Midnight Cave, Blowing Sink, Backdoor Springs, and Bee Springs, suggest that this unit can have a potentially low minimum hydraulic gradient such as $3 \%$. Like the Regional Dense Member, vertical shafts and fissures that cascade vadose flows vertically are frequently observed in caves developed within the Dolomitic Member

For low permeable units, the source can potentially

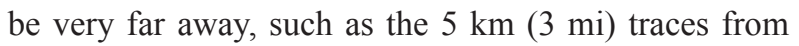
Buttercup Creek to Blizzard Springs.

\section{Conclusion}

The source area to cave drips and cave streams can be delineated using a combination of drip characterization, cave drip elevation and spatial mapping, geologic framework mapping, water-quality characterization, and direct groundwater tracing. Drip characterization

Table 2. Measured hydraulic gradients across various hydrostratigraphic units associated with the Edwards Aquifer.

\begin{tabular}{|c|c|c|c|c|c|}
\hline Year & Trace & Hydrostratigraphic Unit(s) Tested & $\begin{array}{c}\text { Distance } \\
(\mathrm{m})\end{array}$ & $\begin{array}{c}\text { Depth } \\
(\mathrm{m})\end{array}$ & $\begin{array}{c}\text { Gradient } \\
(\%)\end{array}$ \\
1997 & Marigold & Walnut Formation & 6,116 & 23 & $0.4 \%$ \\
\hline 1997 & Whitewater & ComanchePk/Walnut Formation & 5,472 & 56 & $1.0 \%$ \\
\hline 2007 & Flat Depression & Grainstone/Kirschberg Member & 26 & 7 & $26 \%$ \\
\hline 2007 & Sister Depression & Grainstone/Kirschberg Member & 34 & 7 & $19 \%$ \\
\hline 2007 & Snakehole & Grainstone/Kirschberg Member & 67 & 8 & $12 \%$ \\
\hline 2007 & Fieldsoil & Grainstone/Kirschberg Member & 65 & 8 & $12 \%$ \\
\hline 2010 & Wade Sink & Leached/Collapsed/Regional Dense Mbr & 852 & 25 & $3 \%$ \\
\hline 2010 & Hideout Sink & Leached/Collapsed/Regional Dense Mbr & 929 & 26 & $3 \%$ \\
\hline
\end{tabular}


includes measurements in variation of drip rate and spelothem type associated with drip to categorize discrete or seepage source. Non-persistent, widely distributed, soda straw drips may be associated with approximately overlying soil and epikarst drainage. Deeper within the cave systems, discrete drips commonly represent the convergence of smaller flows or a major flow source. Speleothems associated with discrete drips tend to be flowstone cascades, large stalagtites and stalagmites, and rimstone dams. Even where only widely distributed, seepage drips are present, the subsurface catchment area can be assumed to extend at least $100 \mathrm{~m}$ beyond the cave footprint, unless direct data suggests a smaller subsurface catchment.

Subsurface catchment areas over highly permeable units, such as the Leached, Collapsed, Grainstone, and Kirschberg Members tend to be smaller than subsurface catchment areas over low permeable units such as the Regional Dense Member, Dolomitic Member, and Basal Nodular Member (identical to the thicker Walnut Formation north of the Colorado River). For the purposes of estimating subsurface catchment areas, minimum hydraulic gradients of $10 \%$ can be used to estimate surface extent from cave drips overlain by only high permeable units while hydraulic gradients as low as 0.4 to $3 \%$ may be associated with vadose flow over lower permeable units.

Vadose groundwater is generally, but not always, directed in the downdip direction or down faulted blocks. Specific faults, fractures, and fissures may direct parallel groundwater flow within lower permeable units to local discharge sites. In general, it is advisable to extend the subsurface catchment area in the updip or upthrown fault direction to the full outcrop of rocks overlying the drip, even if it exceeds the area defined by hydraulic gradient, unless the source area can be refined by direct tracing. Water-quality characteristics can be used to relate drips of similar source and characterize source areas. Groundwater tracing is the most direct method to associate a surface site and cave drip. Because of the complexities of macropore flow through soils and groundwater flow through the epikarst, vadose, and phreatic zones, a hydrogeological study constrained by conjunctive data such as geological mapping, direct tracing, waterquality sampling, and cave drip surveys delineates the subsurface catchment area with high confidence.

\section{References}

Collins EW. 1995. Structural framework of the Edwards Aquifer, Balcones Fault Zone, Central Texas: Gulf Coast Association of Geological Societies Transactions 45:135-142.

Compton RR. 1961. Manual of field geology. New York (NY): John Wiley \& Sons.

Cowan BC, Banner JL, Hauwert NM, Musgrove ML. 2007. Geochemical and physical tracing of rapid response in the vadose zone of the Edwards karst aquifer. Geological Society of America Annual Meeting Paper 69-3.

Dasher, G. 1994. On station. National Speleological Society publication.

Dugas WA, Hicks RA, Wright P. 1998. Effect of removal of Juniperus ashei on evapotranspiration and runoff in the Seco Creek watershed. Water Resources Research 34 (6):1499-1506.

Ford DC, Williams, P. 1992. Karst geomorphology and hydrology. 2nd ed. Chapman and Hall Publishers.

Goldscheider N. 2005. Fold structure and underground drainage pattern in the alpine karst system Hochifen-Gottesacker. Eclogae Geologicae Helvetiae 98: 1-17.

Goldscheider N, Drew D, editors. 2007. Methods in Karst Hydrogeology. International Association of Hydrogeologists 26. Leiden (Netherlands):Taylor \& Francis.

Ginsberg M, Palmer A. 2002. Delineation of source-water protection areas in karst aquifers of the Ridge and Valley and Appalachian Plateaus physiographic provinces, rules of thumb for estimating the capture zones of springs and wells: EPA report 816-R-02-015.

Hauwert N, Warton M. 1997. Initial groundwater tracing study of Buttercup Creek area, Cedar Park, south Williamson County, Texas. Report by Mike Warton \& Assoc. to USFW Service.

Hauwert N, Johns D, Sansom J, and Aley T. 2004. Groundwater tracing study of the Barton Springs Segment of the Edwards Aquifer, southern Travis and northern Hays counties, Texas. Barton Springs/ Edwards Aquifer Conservation District and City of Austin Watershed Protection Department.

Hauwert N. 2009. Groundwater flow and recharge within the Barton Springs Segment of the Edwards Aquifer, Southern Travis County and Northern Hays County, Texas. [Ph.D. Diss.] Austin (TX): University of Texas at Austin. 328 p.

Hauwert N. 2010. Hydrogeologic Study of Fossil Garden, No Rent, Weldon, and McNeil Bat Caves. City of Austin short report SR-11-21.81 p. 
Hauwert N. 2012a. Dye Trace Simulation of an Accidental Spill Phase 10: State Highway 45 Southwest and MoPac South into the Barton Springs Segment of the Edwards Aquifer Travis County, Texas: City of Austin Watershed Protection Dept. short report SR13-01. 75 p.

Hauwert N. 2013 in review. Stream Recharge to the Barton Springs Segment of the Edwards Aquifer, Southern Travis and Northern Hays Counties, Texas. City of Austin Watershed Protection Dept. short report.

Jeannin P, Groves C, Hauselmann P. 2007. Speleological investigations. In: Goldsneider G., Drew, D. editors. Methods in karst hydrogeology. International Association of Hydrogeologists 26 Leiden (Netherlands):Taylor \& Francis. P. 25-44.

Maclay RW, Small TA. 1984. Carbonate geology and hydrology of the Edwards Aquifer in the San Antonio area, Texas. U.S. Geological Survey Open-File Report 83-537.

Ochel D, Shade B. Cave survey using tape/Disto and instruments. [Internet]. 2013. [Austin, TX]: University of Texas Grotto; [updated 2013 January; cited 2013 February 8]. Available from: http:// utgrotto.org/articles/SurveyBasics.asp

Palmer A. 1977. Influences of geologic structure on groundwater flow and cave development in Mammoth Cave National Park, Kentucky, USA: International Association of Hydrogeologists, 12th Memoirs, p. 405-414.

Palmer A. 2007. Cave Geology, Dayton, (OH): Cave Books.

Quinlan JF, Ray JA, Schindel, GM. 1995. Intrinsic limitations of standard criteria and methods for delineation of groundwater-source protection areas (springhead and wellhead protection areas) in carbonate terranes. In: Beck, B. ed. Karst Geohazards Engineering and Environment, P.525-540.

Rose PR. 1972. Edwards Group, surface and subsurface, central Texas. The University of Texas Bureau of Economic Geology Report of Investigations 74.

Slade R, Dorsey M, Stewart S. 1986. Hydrology and water quality of the Edwards Aquifer associated with Barton Springs in the Austin Area, Texas. USGS Water-Resources Investigations Report 86-4036.

Small TA, Hanson JA, and Hauwert NM. 1996. Geologic framework and hydrogeologic characteristics of the Edwards Aquifer outcrop (Barton Springs Segment), northeastern Hays and southwestern Travis Counties, Texas. U.S. Geological Survey Water Resources Investigations 96-4306.

Veni G. 1992. Geologic controls on cave development and the distribution of cave fauna in the Austin, Texas Region. Report to U.S. Fish and Wildlife Service.
United States Fish and Wildlife Service. 1996. Final Environmental Impact Statement/Habitat Conservation Plan for Proposed Issuance of a Permit to Allow Incidental Take of the Goldencheeked Warbler, Black-capped Vireo, and Six Karst Invertebrates in Travis County, Texas.

White W. 1988. Geomorphology and hydrology of karst terrains. New York (NY): Oxford University Press.

Woodruff CM. 1984. Water budget analysis for the area contributing recharge to the Edwards Aquifer, Barton Springs Segment. In: C. Woodruff and R. Slade, ed., Hydrogeology of the Edwards Aquifer-Barton Springs Segment, Travis and Hays Counties, Texas. Austin (TX): Austin Geological Society Guidebook 6, p. 36-42. 
